\title{
UJI AKTIVITAS ANTIOKSIDAN EKSTRAK ETANOL 96\% KOMBINASI BUAH STRAWBERRY DAN TOMAT DENGAN METODE ABTS
}

\author{
Diana Serlahwaty*, Atika Nourmela Sevian \\ Universitas Pancasila, Srengseng Sawah Jagakarsa Jakarta Selatan \\ *Email: dianas_ffup@yahoo.co.id
}

\begin{abstract}
ABSTRAK
Buah-buahan merupakan salah satu sumber antioksidan yang diharapkan berguna bagi kesehatan. Strawberry (Fragaria $x$ ananassa Duch.) kaya akan vitamin C, pigmen warna antosianin serta asam ellagat sedangkan buah tomat (Lycopersicon esculentum Mill.) mengandung vitamin A, C, E, serta likopen yang mempunyai aktivitas dalam meredam radikal bebas. Penelitian ini bertujuan mengetahui aktivitas antioksidan dengan metode ABTS menggunakan spektrofotometer cahaya tampak pada panjang gelombang $412 \mathrm{~nm}$ terhadap ekstrak tunggal serta kombinasi ekstrak strawberry dan tomat dengan perbandingan bobot $1: 1 ; 1: 3 ; 3: 1$ menggunakan vitamin $C$ sebagai kontrol positif. Buah strawberry dan tomat diekstraksi secara maserasi menggunakan pelarut etanol $96 \%$. Hasil uji aktivitas antioksidan ekstrak tunggal buah strawberry lebih kuat dibanding buah tomat dengan nilai $\mathrm{IC}_{50}$ masing-masing sebesar 21.79 bpj dan 83.21 bpj, sedangkan aktivitas antioksidan kombinasi ekstrak strawberry dan tomat dengan perbandingan bobot 1:1; 1:3; 3:1 diperoleh nilai $\mathrm{IC}_{50}$ sebesar $47.61 \mathrm{bpj}, 58.61 \mathrm{bpj}$ dan $30.73 \mathrm{bpj}$, sehingga dapat disimpulkan aktivitas antioksidan terkuat terdapat pada kombinasi ekstrak strawberry dan tomat pada perbandingan bobot 3:1 dengan $\mathrm{IC}_{50}$ sebesar 30.73 bpj. Dari hasil uji statistik menggunakan metode ANAVA 1 arah menunjukkan ada perbedaan aktivitas antioksidan yang signifikan antara ekstrak tunggal serta semua perbandingan kombinasi ekstrak etanol buah strawberry dan tomat.
\end{abstract}

Kata Kunci : buah strawberry, tomat, ABTS, antioksidan

\begin{abstract}
Fruits are one of the antioxidants source which are expected to be useful for health. Strawberry (Fragaria $x$ ananassa Duch.) rich in vitamin C, anthocyanin pigments and ellagic acid while tomato fruit (Lycopersicon esculentum Mill.) contains vitamins A, C, E, and lycopene which have the activity to reducing free radicals. The aim of this research is to determine the antioxidant activity using ABTS method by visible spectrophotometer at $412 \mathrm{~nm}$ against single extracts and combination extract of strawberry and tomato with a weight ratio of $1: 1 ; 1: 3 ; 3: 1$ using vitamin $C$ as a positive control. Strawberry and tomato fruit, were extracted by maceration using ethanol $96 \%$ as solvent. The results of the antioxidant activity test of single extract strawberry fruit is stronger than the tomato fruit with $\mathrm{IC}_{50}$ values of $21.79 \mathrm{ppm}$ and $83.21 \mathrm{ppm}$ respectively. While the antioxidant activity extracts of strawberry and tomato combination with a weight ratio of 1:1; 1:3; 3:1 obtained IC50 value of $47.61 \mathrm{ppm}, 58.61 \mathrm{ppm}$ and $30.73 \mathrm{ppm}$ respectively. It can be concluded that the strongest antioxidant activity found in the combination of strawberry and tomato extract on weight ratio 3: 1 with IC50 equals to $30.73 \mathrm{ppm}$. Results of statistical tests using
\end{abstract}


1-way ANOVA showed the significant differences between antioxidant activity among all comparisons of ethanol extract combination both strawberries and tomatoes.

Keywords : strawberry fruit, tomato fruit, ABTS, antioxidant

\section{PENDAHULUAN}

Dalam kehidupan sehari-hari, kita tidak dapat terbebas dari senyawa radikal bebas. Asap rokok, makanan yang digoreng, dibakar, paparan sinar matahari berlebih, asap kendaraan bermotor, obat-obat tertentu, racun dan polusi udara merupakan beberapa sumber pembentuk senyawa radikal bebas. Radikal bebas merupakan atom molekul yang memiliki satu atau lebih elektron tidak berpasangan yang menyebabkan menjadi senyawa yang sangat reaktif terhadap sel-sel tubuh dengan cara mengikat elektron molekul sel. Reaksi ini sering disebut sebagai oksidasi. Oksidasi yang berlebihan di dalam tubuh dapat menginisiasi terjadinya penyakit seperti jantung koroner, penuaan dini, katarak, gangguan kognisi, kanker dan penyakit degeneratif lainnya. Antioksidan merupakan senyawa yang dapat memperlambat proses oksidasi dari radikal bebas. Mekananisme kerja senyawa antioksidan salah satunya yaitu dengan cara mendonorkan atom hidrogen atau proton kepada senyawa radikal. Hal ini menjadikan senyawa radikal lebih stabil.

Strawberry (Fragaria $x$ ananassa Duch.) kaya akan pigmen warna antosianin yang mengandung antioksidan tinggi. Beberapa manfaat buah strawberry yang telah diketahui adalah untuk menurunkan kadar kolesterol, membantu melumpuhkan kerja aktif kanker karena asam ellagat yang dikandungnya, meredam gejala stroke, mengandung zat anti alergi, anti radang, dan hanya mengandung sedikit gula sehingga cocok bagi pengidap diabetes. Antioksidan di dalam strawberry memberikan perlindungan pada hati, dan antiinflamasi. Tomat (Lycopersicon esculentum Mill.) mengandung lemak, rendah kalori, serta merupakan sumber serat dan protein yang baik. Selain itu, buah tomat kaya akan vitamin A, C, dan E, beta-karoten, kalium serta likopen yang mempunyai aktivitas dalam meredam radikal bebas. Penggunaan antioksidan dalam masyarakat untuk menangkal radikal bebas telah mengalami peningkatan. Masyarakat mulai sadar akan pentingnya penggunaan antioksidan untuk menangkal penyakit yang disebabkan oleh radikal bebas. Inovasi terus dilakukan untuk mendapatkan antioksidan. Dalam penggunaan kedepannya, diharapkan kombinasi antara kedua buah tersebut dapat dijadikan sebagai pangan fungsional yang berfungsi sebagai antioksidan. Menurut Badan Pengawasan Obat dan Makanan (POM), pangan fungsional adalah pangan yang secara alami maupun melalui proses mengandung satu atau lebih senyawa berdasarkan hasil kajian ilmiah, dianggap mempunyai fungsi-fungsi fisiologis tertentu yang bermanfaat bagi kesehatan. Pangan fungsional disajikan dan dikonsumsi layaknya makanan atau minuman, mempunyai karakteristik sensori berupa penampakan, warna, tekstur dan cita rasa yang dapat diterima oleh konsumen, serta tidak memberikan kontraindikasi dan tidak memberikan efek samping terhadap metabolisme zat gizi lainnya.Di pasaran banyak beredar produk minuman fungsional yang tersedia dalam berbagai bentuk, seperti jus (sari buah), serbuk minuman cepat larut (serbuk instan), serta dalam bentuk teh herbal (teh celup).

Metode yang digunakan untuk mengetahui aktivitas antioksidan adalah metode peredaman radikal bebas asam 2,2'azino-bis(3-etilbenzatiazolin-6-sulfonat) (ABTS). Metode peredaman radikal bebas ABTS merupakan metode pengujian untuk mengukur jumlah radikal bebas yang dapat ditangkal oleh antioksidan yang dikenal dengan aktivitas antioksidan. Selain memiliki sensitivitas yang cukup tinggi, kelebihan ABTS dibandingkan dengan metode lain yaitu pengujiannya yang sederhana, efektif, cepat, dan mudah diulang. Metode ABTS dapat digunakan untuk mengetahui konsentrasi antioksidan yang mampu 
menghambat radikal bebas sebanyak 50\% ( $\left.\mathrm{IC}_{50}\right)$. Penggunaan metode peredaman radikal bebas ABTS pada pengujian antioksidan dalam buah telah banyak digunakan, seperti penelitian yang dilakukan Ji Sae Rom Lee et al. menunjukkan nilai IC $_{50}$ dari ekstrak etanol $60 \%$ buah rasberry pada panjang gelombang $734 \mathrm{~nm}$ sebesar $251 \mu \mathrm{g} / \mathrm{ml}$.

Berdasarkan penelitian ekstrak buah strawberry sebelumnya diperoleh informasi ekstrak etanol 96\%, etil asetat dan n-heksan buah strawberry memiliki iC $\mathrm{C}_{50}$ berturut-turut sebesar 53.12 bpj, 76.69 bpj, dan 144.52 bpj. Hal tersebut menunjukkan bahwa aktivitas antioksidan pada ekstrak etanol $96 \%$ buah strawberry lebih kuat dibandingkan ekstrak etil asetat dan ekstrak n-heksan buah strawberry. Penelitian terhadap ekstrak etanol buah tomat diperoleh $\mathrm{IC}_{50}$ sebesar 36.13 bpj. Oleh karena itu, penulis melakukan penelitian terhadap ekstrak tunggal serta kombinasi ekstrak etanol $96 \%$ buah strawberry dan tomat yang mengandung antioksidan kuat. Pada buah strawberry dan tomat segar dilakukan penetapan susut pengeringan. Pembuatan ekstrak secara maserasi menggunakan pelarut etanol $96 \%$. Selanjutnya maserat diuapkan sampai didapatkan ekstrak etanol 96\%. Ekstrak yang didapat dari kedua buah tersebut dikombinasi dengan perbandingan bobot ekstrak 1:1; 1:3; 3:1. Ekstrak kental yang diperoleh dilakukan penetapan kadar air. Kemudian, ekstrak tunggal dan ekstrak kombinasi tersebut diuji aktivitas antioksidannya menggunakan metode peredaman radikal bebas ABTS pada panjang $412 \mathrm{~nm}$ dengan vitamin C sebagai kontrol positif.

\title{
METODE PENELITIAN
}

\section{Bahan:}

1. Buah segar strawberry dan buah segar tomat.

2. Bahan kimia dan pereaksi, yaitu: Etanol 96\%, Etanol pro analisis, ABTS, kalium persulfat, vitamin C, ammonia 30\%, kloroform, asam klorida, pereaksi Dragendorff dan Mayer, serbuk atau lempeng magnesium, aquadest, besi (III) klorida 1\%, natrium hidroksida $1 \mathrm{~N}$, pereaksi Lieberman-Burchard, pereaksi Stiasny, natrium asetat, eter, asam asetat anhidrat, asam sulfat pekat, amil alkohol.

\begin{abstract}
Alat:
Alat yang digunakan pada penelitian ini adalah Spektrofotometer UV-VIS (Shimadzu UV1800), Rotavapor (IKA ® RV 10 control), Moisturemeter Karl Fischer (Metrohm 870 KF), inkubator (Memmert), Oven (Memmert), timbangan analitik (AND GR 200), Water Bath (Julabo TW20) dan alat-alat gelas.
\end{abstract}

\section{PROSEDUR}

Penelitian terhadap ekstrak tunggal serta kombinasi ekstrak etanol 96\% buah strawberry dan tomat yang mengandung antioksidan kuat. Pada buah strawberry dan tomat segar dilakukan penetapan susut pengeringan. Pembuatan ekstrak secara maserasi menggunakan pelarut etanol $96 \%$. Selanjutnya maserat diuapkan sampai didapatkan ekstrak etanol 96\%. Ekstrak yang didapat dari kedua buah tersebut dikombinasi dengan perbandingan bobot ekstrak $1: 1 ; 1: 3 ; 3: 1$. Ekstrak kental yang diperoleh dilakukan penetapan kadar air. Kemudian, ekstrak tunggal dan ekstrak kombinasi tersebut diuji aktivitas antioksidannya menggunakan metode peredaman radikal bebas ABTS pada panjang gelombang $412 \mathrm{~nm}$ dengan vitamin $\mathrm{C}$ sebagai kontrol positif. 


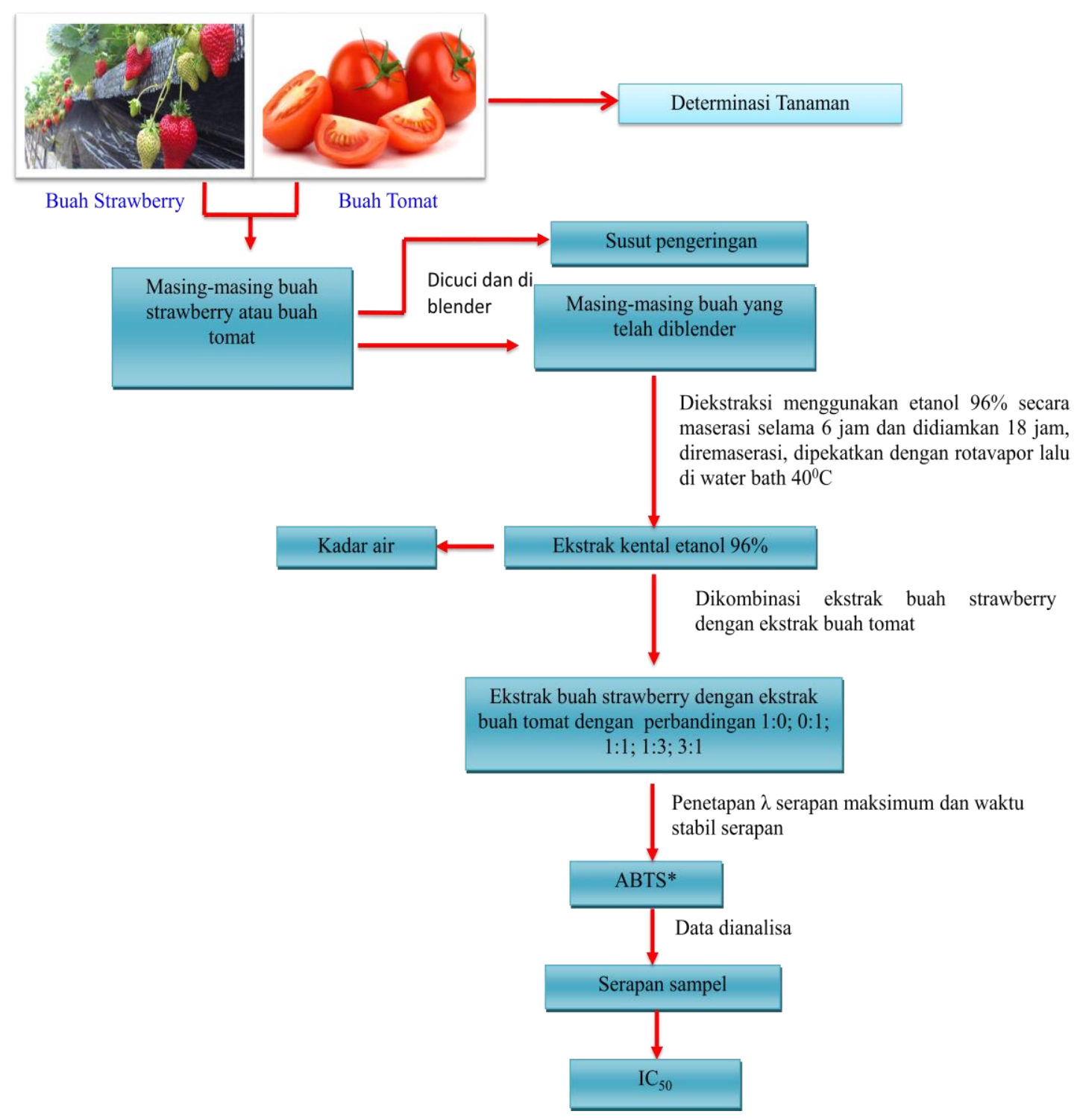

Gambar 1. Skema kerja peneitian

\section{HASIL DAN PEMBAHASAN}

\section{Hasil Penetapan Susut Pengeringan}

Penetapan susut pengeringan dilakukan dengan cara pemanasan buah segar strawberry dan tomat pada suhu $105^{\circ} \mathrm{C}$ dan ditimbang sampai diperoleh bobot konstan. Diperoleh susut pengeringan buah segar strawberry sebesar 90,19\%, buah segar tomat sebesar 95,27\%. Hasil penetapan susut pengeringan dapat dilihat di Tabel 1. 
Tabel 1 Hasil penetapan susut pengeringan

\begin{tabular}{|c|c|c|c|c|}
\hline \multirow[b]{2}{*}{ Jenis sampel } & \multicolumn{2}{|c|}{ Bobot (gram) } & \multirow{2}{*}{$\begin{array}{c}\text { Susut } \\
\text { pengeringan } \\
(\%)\end{array}$} & \multirow{2}{*}{$\begin{array}{c}\text { Susut } \\
\text { pengeringan } \\
\text { rata-rata }(\%)\end{array}$} \\
\hline & $\begin{array}{c}\text { Sebelum } \\
\text { dikeringkan }\end{array}$ & $\begin{array}{c}\text { Setelah } \\
\text { dikeringkan }\end{array}$ & & \\
\hline \multirow{3}{*}{$\begin{array}{l}\text { Buah segar } \\
\text { strawberry }\end{array}$} & 2,10 & 0,19 & 90,95 & \multirow[t]{3}{*}{90,19} \\
\hline & 2,03 & 0,19 & 90,64 & \\
\hline & 2,18 & 0,24 & 88,99 & \\
\hline \multirow{3}{*}{$\begin{array}{c}\text { Buah segar } \\
\text { tomat }\end{array}$} & 2,13 & 0,08 & 96,24 & \multirow[t]{3}{*}{95,27} \\
\hline & 2,15 & 0,09 & 95,81 & \\
\hline & 2,08 & 0,13 & 93,75 & \\
\hline
\end{tabular}

\section{Hasil Penetapan Kadar Air}

Penetapan kadar air dari masing-masing ekstrak buah strawberry dan ekstrak buah tomat ditetapkan dengan alat Moisturemeter Karl Fischer. Secara volumetrik berdasarkan prinsip titrasi. Titran yang digunakan adalah pereaksi Karl Fischer yang dibuat dari campuran iodin, sulfurdioksida, dan piridin dalam larutan metanol. Dari pengujian diperoleh kadar air ekstrak etanol buah strawberry 5,93\% dan kadar air ekstrak etanol buah tomat 7,24\% hal tesebut menunjukkan ekstrak etanol buah strawberry dan buah tomat memenuhi persyaratan. Hasil pengukuran kadar air dapat dilihat pada Tabel 2.

Tabel 2. Hasil pengukuran kadar air ekstrak kental etanol $96 \%$

\begin{tabular}{cc}
\hline Jenis sampel & Kadar air (\%) \\
\hline Ekstrak kental etanol 96\% buah strawberry & 5,93 \\
Ekstrak kental etanol 96\% buah tomat & 7,24 \\
\hline
\end{tabular}

\section{Hasil Pembuatan Ekstrak}

Buah segar strawberry (Fragaria x ananassa Duch.) sebanyak 1015,94 gram dan sejumlah 1650,08 gram buah segar tomat (Lycopersicon esculentum Mill.) masing-masing diekstraksi sempurna dengan maserasi selama 24 jam pada suhu kamar menggunakan pelarut etanol $96 \%$ terdestilasi sebanyak masing-masing $7 \mathrm{~L}$ dan $15.2 \mathrm{~L}$. Maserat yang diperoleh dikumpulkan dan dipekatkan dengan menggunakan rotavapor. Mekanisme kerja pada proses ekstraksi yaitu memecahkan dinding sel dan membran sel karena adanya kondisi jenuh antara di dalam dan di luar sel sehingga metabolit sekunder yang ada di dalam sel tertarik keluar dan larut kedalam pelarutnya. Hasil maserasi diperoleh ekstrak kental buah strawberry sejumlah 44.9 gram dengan rendemen $4.41 \%$ dan ektrak buah tomat sejumlah 82.89 gram dengan rendemen 5.02\% (Tabel 3). Semakin tinggi persentase rendemen yang diperoleh maka semakin baik proses ekstraksi yang dilakukan.

Tabel 3. Hasil pembuatan ekstrak buah strawberry dan tomat

\begin{tabular}{ccc}
\hline Jenis buah & $\begin{array}{c}\text { Bobot ekstrak } \\
\text { (gram) }\end{array}$ & $\begin{array}{c}\text { Rendemen } \\
(\%)\end{array}$ \\
\hline Strawberry & 44.79 & 4.41 \\
Tomat & 82.89 & 5.02 \\
\hline
\end{tabular}




\section{Penetapan Panjang Gelombang Serapan Maksimum Larutan ABTS}

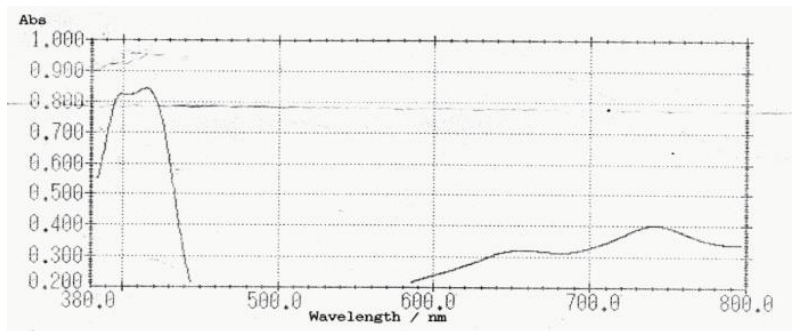

Gambar 2. Spektrum serapan larutan ABTS

Spektrum serapan larutan ABTS dalam etanol diperoleh 4 panjang gelombang maksimum yaitu 396.5, 412, 658, dan $744 \mathrm{~nm}$. Namun, serapan tertinggi diperoleh pada panjang geombang 412 dengan serapan maksimum 0,8540 . Berdasarkan literatur terdapat beberapa panjang gelombang maksimum dari larutan ABTS yaitu pada panjang gelombang 414, 645 dan $734 \mathrm{~nm}$. Oleh karena itu pengujian aktivitas antioksidan dilakukan pada panjang gelombang $412 \mathrm{~nm}$.

\section{Penetapan Waktu Stabil}

Penetapan waktu stabil dilakukan dengan mengukur serapan larutan vitamin $\mathrm{C}$ dalam etanol pro analisis dan direaksikan dengan larutan blanko ABTS $7 \mathrm{mM}$ menggunakan spektrofotometer cahaya tampak pada panjang gelombang serapan maksimum dimulai dari menit ke 2, 4, 6, 8, 10, 12, 14, 16, 18 dan 20. Hasil penetapan waktu stabil menunjukkan bahwa larutan ABTS setelah ditambahkan kalium persulfat dalam pelarut etanol memberikan serapan yang stabil pada menit ke 6-8. Oleh karena itu pengukuran serapan sebaiknya dilakukan pada menit ke 6-8, hal tersebut sesuai dengan beberapa literatur yang di rekomendasikan yaitu 6 menit.

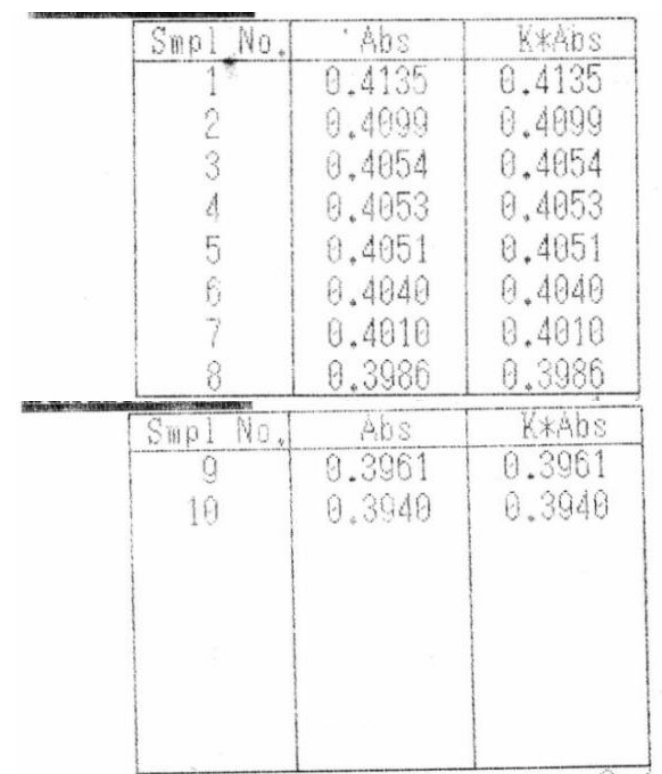

Gambar 3 Serapan larutan ABTS pada menit ke 2-20 


\section{Uji Aktivitas Antioksidan dengan Metode Peredaman Radikal Bebas ABTS}

Uji aktivitas antioksidan dengan menggunakan radikal bebas ABTS dilakukan pada ekstrak kental etanol $96 \%$ buah strawberry dan tomat, serta vitamin C sebagai kontrol positif. Aktivitas antioksidan ditenttukan dengan nilai $\mathrm{IC}_{50}(\mathrm{bpj})$ yang diperoleh dari perpotongan garis antara 50\% peredaman radikal bebas dengan sumbu konsenstrasi larutan uji.

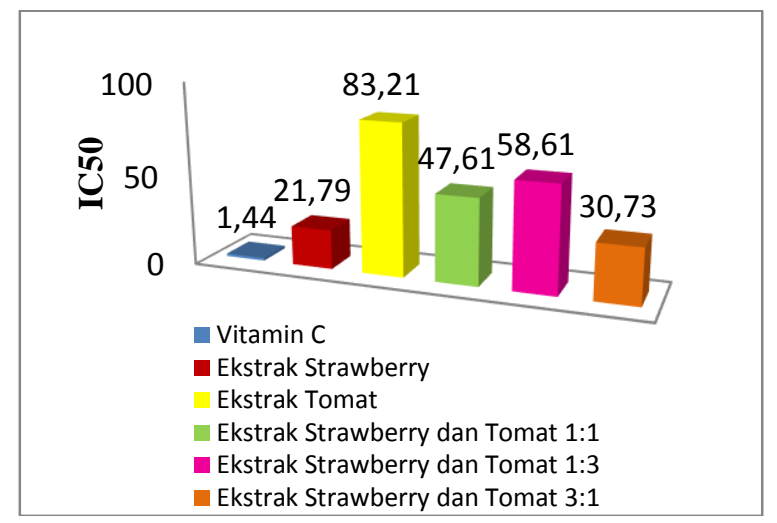

Gambar 4. Hasil uji aktivitas antioksidan ekstrak dengan metode ABTS

\section{UJI STATISTIK}

Uji statistik data dilakukan dengan menggunakan metode ANAVA 1 arah, sebab dalam penelitian ini hanya terdapat 1 variabel yaitu perbandingan ekstrak yang digunakan.

$\mathrm{H}_{0}$ : - Tidak terdapat perbedaan aktivitas antioksidan yang sinergis pada ekstrak tunggal serta kombinasi ekstrak buah strawberry dan tomat perbandingan bobot 1:1; 1:3; $3: 1$. $\mathrm{H}_{1}$ : - Terdapat perbedaan aktivitas antioksidan yang sinergis pada ekstrak tunggal serta kombinasi ekstrak buah strawberry dan tomat perbandingan bobot 1:1;1:3;3:1.

Hasil uji ANAVA

$\begin{array}{ll}\text { F hitung } & : 793,597 \\ \text { F tabel } & : 3,47805\end{array}$

Keputusan : f hitung lebih besar dari $\mathrm{f}$ tabel, maka $\mathrm{H}_{0}$ ditolak dan $\mathrm{H}_{1}$ diterima. Sehingga ada perbedaan bermakna yang sinergis antara aktivitas antioksidan pada ekstrak tunggal serta kombinasi ekstrak etanol $96 \%$ buah strawberry (Fragaria x ananassa Duch.) dan buah tomat (Lycopersicon esculentum Mill.) 1:1; 1:3; 3:1.

\section{PEMBAHASAN.}

Strawberry dan tomat yang diukur aktivitas antioksidannya dibuat dalam bentuk ekstrak kental. Pelarut yang digunakan dalam pembuatan ekstrak kental adalah etanol $96 \%$. Pemilihan pelarut ini berdasarkan literatur acuan yang menyatakan bahwa strawberry dan tomat memiliki aktivitas antioksidan yang kuat dalam pelarut ini dibandingkan dengan pelarut lain yang telah diteliti. Etanol $96 \%$ juga merupakan pelarut universal yang dapat menarik senyawa-senyawa besar, seperti flavonoid, dengan baik sehingga senyawa flavonoid pada buah dapat ditarik sempurna oleh pelarut. Etanol $96 \%$ juga memenuhi persyaratan pelarut yang baik, seperti selektif, ekonomis, ramah lingkungan, dan tergolong aman. Sifat etanol 96\% yang mudah menguap dan kemampuannya menghambat pertumbuhan mikroba juga menjadi dasar pertimbangan pemilihan pelarut. 
Aktivitas antioksidan dinyatakan dalam $\mathrm{IC}_{50}$. Nilai $\mathrm{IC}_{50}$ (bpj) menunjukkan konsentrasi sampel yang dapat menghambat $50 \%$ radikal bebas. Semakin kecil nilai $\mathrm{IC}_{50}$ maka akan semakin kuat aktivitas antioksidan dari sampel tersebut.

Nilai IC $_{50}$ pada Vitamin C memberikan aktivitas antioksidan sebesar 1,44 bpj. Dalam uji aktivitas antioksidan dengan ABTS, Vitamin C digunakan sebagai kontrol positif. Dapat dilihat bahwa aktivitas antioksidan ekstrak strawberry diperoleh nilai IC $_{50}$ sebesar 21,79 bpj. Hal ini menyatakan bahwa ekstrak strawberry memiliki nilai IC $_{50}$ kurang dari 50 bpj maka dikategorikan sebagai antioksidan sangat kuat. Sedangkan pada penelitian sebelumnya strawberry memiliki tingkat antioksidan kuat dengan nilai $\mathrm{IC}_{50}$ sebesar 53,12 bpj. Perbedaan tingkat antioksidan yang diperoleh dikarenakan perbedaan asal dan perbedaan umur buah strawberry yang digunakan. Ekstrak tomat diperoleh $\mathrm{IC}_{50}$ sebesar 83,21 bpj maka ekstrak tomat dikategorikan memiliki aktivitas antioksidan kuat. Pada penelitian sebelumnya tomat memiliki tingkat antioksidan sangat kuat dengan nilai $\mathrm{IC}_{50}$ sebesar 36,13 bpj. Perbedaan tingkat antioksidan yang diperoleh dikarenakan perbedaan asal dan perbedaan umur buah tomat yang digunakan. Berdasarkan pengujian aktivitas antioksidan kombinasi ekstrak etanol buah strawberry dan buah tomat 1:1 didapat nilai IC $_{50}$ 47,61 bpj. Nilai IC 50 yang diperoleh lebih rendah dibandingkan ekstrak tunggal strawberry namun lebih tinggi dibandingkan ekstrak tunggal tomat. Pada pengujian aktivitas antioksidan kombinasi 1:3 diperoleh nilai $\mathrm{IC}_{50}$ 58,61 bpj. Sedangkan ekstrak kombinasi 3:1 diperoleh nilai $\mathrm{IC}_{50} 30,73$ bpj maka berdasarkan nilai $\mathrm{IC}_{50}$ yang diperoleh dari kombinasi ekstrak etanol buah strawberry dan buah tomat dengan perbandingan 3:1 memiliki aktivitas antioksidan paling kuat. IC $_{50}$ yang diperoleh dari kombinasi ekstrak buah strawberry dan buah tomat tidak lebih kuat dari nilai $\mathrm{IC}_{50}$ ekstrak tunggal buah strawberry, hal ini disebabkan karena dari hasil penelitian diperoleh nilai IC $_{50}$ ekstrak tunggal buah tomat jauh lebih rendah dibandingkan nilai $\mathrm{IC}_{50}$ ekstrak buah strawberry. Antioksidan dari ekstrak buah tomat tidak mampu menaikkan antioksidan ekstrak buah strawberry sehingga nilai $\mathrm{IC}_{50}$ dari kombinasi ekstrak buah tidak lebih kuat dari ekstrak tunggal buah strawberry namun dapat meningkatkan $\mathrm{IC}_{50}$ ekstrak tunggal buah tomat.

\section{SIMPULAN}

1. Aktivitas antioksidan kombinasi ekstrak buah strawberry dan buah tomat dengan perbandingan bobot $1: 1 ; 1: 3 ; 3: 1$ masing-masing diperoleh nilai $\mathrm{IC}_{50} ; 47,61 \mathrm{bpj} ; 58,61$ bpj; 30,73 bpj, yang menunjukkan aktivitas antioksidan tertinggi pada kombinasi ekstrak strawberry dan tomat dengan perbandingan 3:1 yaitu sebesar 30,73 bpj. Hasil uji statistik menggunakan metode ANAVA 1 arah menunjukkan ada perbedaan aktivitas antioksidan yang signifikan antara semua perbandingan kombinasi ekstrak etanol buah strawberry dan buah tomat.

2. Aktivitas antioksidan ekstrak tunggal buah strawberry lebih kuat dibandingkan dengan eksrak tunggal buah tomat yang ditunjukkan dengan nilai $\mathrm{IC}_{50} 21,79 \mathrm{bpj}$ dan 83,21 bpj, tapi masih lebih rendah dibandingkan dengan nilai $\mathrm{IC}_{50}$ vitamin $\mathrm{C}$ sebagai kontrol positif yaitu $1,44 \mathrm{bpj}$.

\section{DAFTAR PUSTAKA}

1. Pietta P-G. Flavonoids as Antioxidants, Reviews. J. Nat. Prod. 1999; 63, 1035-42 dikutip dari Umayah E, Amrun M. Uji aktivitas antioksidan ekstrak buah naga (Hylocereus undatus (Haw.) Britt. \& Rose). Jurnal Ilmu Dasar. 2007; 8(1): h.83.

2. Shui GH, Leong LP. Analysis of polyphenolics antioxidants in star fruit using liquid chromatography and mass spectrometry. J chromatograph A. 2004. 1022:67-75 dikutip dari Abdul R, Sugeng R, Rizka D, Dimas BP. Penangkapan radikal 2,2-difenil-1-pikril hidrazil oleh ekstrak buah Psidium guajava L. dan Averrhoa carambola L. Jurnal Ilmu 
Kefarmasian Indonesia. Jakarta: Fakultas Farmasi Universitas Pancasila; 2009. Vol 7, No 1. h. 1-5.

3. Jeong $\mathrm{JH}$, et al. Anti-oxidant, anti-proliferative and anti-inflammatory activities of the extract from black raspberry fruits and wine. Food Chemistry. 2010;123(2): p. 338344.

4. Yuniati, FU. Daya penangkapan radikal ekstrak etanol 96\% Buah Tomat (Solanum lycopersicum Linn.) dengan metode 2,2-diphenil-1-picrylhidrazil (DPPH). (skripsi). Surakarta: Fakultas Farmasi Universitas Muhammadiyah Surakarta; 2007. h.37.

5. Roberta RE, et al. Antioxidant Activity Applying An Improved ABTS Radical Cation Decolorization Assay. Journal of Biology and Madicine. London: 1999. Vol 26. p.1231-7.

6. Walpole R.E. Pengantar statistik. Edisi ke-3. Jakarta: PT. Gramedia Pustaka Utama; 1995. h. 383-391. 